PETIR: Jurnal Pengkajian dan Penerapan Teknik Informatika Vol. 13, No. 1, Maret 2020, P-ISSN 1978-9262, E-ISSN 2655-5018 DOI: https://doi.org/10.33322/petir.v13i1.858

\title{
Perbandingan Algoritma Long Short-Term Memory dengan SVR pada Prediksi Harga Saham di Indonesia
}

\author{
Adhib Arfan ${ }^{1}$; Lussiana ETP ${ }^{2}$ \\ ${ }^{1}$ Universitas Gunadarma \\ ${ }^{2}$ STMIK Jakarta STI\&K \\ 12adhib.arfan@gmail.com
}

\begin{abstract}
Many investors are still unsure of the risks in investing. It is caused by fluctuations of the stock price index in a short time. Many methods have been developed to estimate the upcoming stock price but they still have limitations, such as long-term dependency. The aims of this research are to produce a more effective forecasting of stock price model and to provide the accurate result. The research steps consist of data collecting, data preprocessing, data sharing, LSTM design, LSTM training, and testing. Based on the test results, LTSM is able to predict stock prices in 2017-2019 in good performance and a relatively little error rates. The test used the Support Vector Regression (SVR) method, LSTM has a better loss value than the SVR algorithm. The data range in the LSTM affects the training time used. The bigger data range is, the longer training time is used. The data range on the SVR affects the loss value. The bigger data range is, the bigger the loss value is generated. Thus, it can be concluded that LSTM is able to overcome long-term dependency and able to predict stock prices with accurate result.
\end{abstract}

Keywords: forecasting, stock price, long short-term memory, support vector regression

\begin{abstract}
ABSTRAK
Banyak investor masih ragu dengan risiko dalam berinvestasi, hal ini disebabkan oleh fluktuasi indeks harga saham dalam waktu singkat. Telah banyak dikembangkan metode untuk memperkirakan harga saham yang akan datang namun masih memiliki keterbatasan di antaranya adalah ketergantungan jangka panjang. Tujuan penelitian yang ingin dicapai adalah menghasilkan model peramalan harga saham yang lebih efektif dan memberikan hasil yang akurat. Tahapan yang dilakukan terdiri dari pengumpulan data, preprocessing data, pembagian data, perancangan LSTM, pelatihan LSTM dan melakukan pengujian. Berdasarkan hasil pengujian, LTSM mampu memprediksi harga saham pada tahun 2017-2019 dengan performa yang baik dan tingkat kesalahan yang relatif kecil. Sedangkan pengujian menggunakan metode Support Vector Regression (SVR), LSTM memiliki nilai loss lebih baik dari algoritma SRV. Rentang data pada LSTM mempengaruhi waktu latih yang digunakan, semakin besar rentang data maka semakin lama waktu latih yang digunakan. Rentang data pada SVR mempengaruhi nilai loss, semakin besar rentang data maka semakin besar nilai loss yang dihasilkan. Dengan demikian dapat disimpulkan bahwa LSTM mampu menanggulangi ketergantungan jangka panjang dan mampu memprediksi harga saham dengan hasil yang akurat.
\end{abstract}

Kata kunci: prediksi, saham, long short-term memory, support vector regression 
PETIR: Jurnal Pengkajian dan Penerapan Teknik Informatika

Vol. 13, No. 1, Maret 2020, P-ISSN 1978-9262, E-ISSN 2655-5018

DOI: https://doi.org/10.33322/petir.v13i1.858

\section{PENDAHULUAN}

Dewasa ini dalam melakukan investasi, tersedia banyak pilihan bagi investor. Investasi bisa berbagai macam bentuknya, salah satu diantaranya adalah investasi saham. Saham adalah hak yang dimiliki seseorang terhadap perusahaan karena penyerahan modal baik itu sebagian maupun keseluruhan[1]. Para investor melakukan investasi saham dan berupaya untuk mendapatkan hasil yang diinvestasikan secara maksimal, akan tetapi banyak investor masih ragu dengan risiko dalam berinvestasi, khawatir yang diinvestasikan tidak sesuai dengan harapan [2]. Keraguan calon investor dalam berinvestasi dikarenakan fluktuasi indeks harga saham dalam waktu yang singkat. Dalam penelitian [3], tentang dampak nilai kurs dan suku bunga dijelaskan bahwa nilai kurs maupun tingkat suku bunga memiliki pengaruh negatif terhadap pasar saham.

Dalam rangka meyakinkan calon investor terhadap keuntungan yang didapat, telah banyak dikembangkan metode untuk memperkirakan harga saham yang akan datang. Metode Back Propagation (BP) yang digunakan dalam pemodelannya[4]. Hasilnya menyatakan bahwa hasil prediksi mendekati kenyataan, sehingga tidak jauh berbeda dengan tren indeks harga saham Bursa Efek Indonesia (BEI), namun hasil tersebut masih terdapat error yang besar. Selanjutnya dikembangkan model dengan menggabungkan metode BP dengan Particle Swarm Optimization (PSO) untuk peramalan indeks harga saham BEI[5], hasilnya dapat memperkecil waktu komputasi dan error dibandingkan dengan model BP saja, tetapi tidak dijelaskan periode saham yang digunakan. Kemudian penelitian tentang penggabungan Support Vector Regression (SVR) dan Jaringan Syaraf Tiruan (JST) untuk memprediksi indeks harga saham[6]. Hasil pengembangan ini dapat menunjukkan performa yang cukup baik, tingkat kesalahan metode SVRJST pada hasil MAPE dan RMSE lebih kecil dibandingkan dengan metode JST pada 3, 7, 10, 15 , dan 30 hari ke depan, namun semakin besar nilai n-hari yang diprediksi menghasilkan tingkat kesalahan semakin besar.

Seiring dengan pengembangan pemodelan dengan menggunakan JST, pada tahun 1997 mulai dikembangkan model baru yang bekerja untuk menangani masalah ketergantungan jangka panjang dan dikenal dengan Long Short-Term memory (LSTM) yang merupakan unit spesial dari Recurrent Neural Network (RNN). Mengacu pada informasi bahwa LSTM dapat menanggulangi permasalahan jangka panjang [7]. Tujuan penelitian ini melakukan peramalan indeks harga saham dengan menggunakan LSTM, tujuan khusus yang ingin dicapai adalah menghasilkan model peramalan harga saham yang lebih efektif dan memberikan hasil yang akurat.

\subsection{Support Vector Regression}

Support Vector Regression (SVR) merupakan pengembangan Support Vector Machine (SVM) untuk kasus regresi. SVM merupakan sebuah cara membagi sebuah dataset ke dalam 2 jenis dataset dengan menggunakan sebuah hyperplane (garis pemisah)[8]. Tujuan SVM adalah membagi dataset (klasifikasi) ke dalam 2 zona, sedangkan tujuan dari SVR sebaliknya, yaitu bagaimana caranya agar semua dataset masuk ke dalam satu zona, dengan tetap meminimasi nilai epsilon $(\varepsilon)$ [9]. Langkahlangkah dalam menggunakan SVR adalah:
a. Menyiapkan data latih
b. Memilih kernel dan parameter serta regulasinya
c. Membuat model untuk mendapatkan koefisien
d. Menggunakan koefisien diatas, kemudian membuat estimatornya. 
PETIR: Jurnal Pengkajian dan Penerapan Teknik Informatika Vol. 13, No. 1, Maret 2020, P-ISSN 1978-9262, E-ISSN 2655-5018 DOI: https://doi.org/10.33322/petir.v13i1.858

\subsection{Long Short-Term Memory}

Long Short Term Memory (LSTM) merupakan sebuah evolusi dari arsitektur Recurrent Neural Network (RNN), di mana pertama kali diperkenalkan oleh Hochreiter \& Schmidhuber (1997)[10]. Hingga penelitian ini dilakukan banyak para peneliti yang terus mengembangkan arsitektur LSTM di berbagai bidang seperti dalam bidang speech recognition dan forecasting[11]. RNN memiliki memori jangka pendek, yaitu tidak dapat membawa informasi yang diperoleh sebelumnya ke proses selanjutnya. Solusi dari teterbatasan yang dimiliki RNN adalah dengan menggunakan LSTM, LSTM merupakan special unit RNN yang didesain untuk menang gulangi ketergantungan jangka panjang dimana LSTM memiliki mekanisme internal yang disebut cell states dan gates yang dapat mengatur memori dalam setiap masukannya[12]. Terdapat empat gates yaitu forget gate, input gate, cell gate dan output gate. Proses pertama yang dilakukan oleh LSTM adalah menentukan nilai yang tidak digunakan (forget gate) dengan rumus sebagai berikut:[13]

$$
f_{t}=\sigma\left(W_{f} \cdot\left[h_{t-1}, x_{t}\right]+b_{f}\right)
$$

Selanjutnya proses menentukan data masukan (input gates) dengan rumus sebagai berikut:

$$
\begin{aligned}
& i_{t}=\sigma\left(W_{i} \cdot\left[h_{t-1}, x_{t}\right]+b_{i}\right) \\
& C_{t}=\tanh \left(W_{c} \cdot\left[h_{t-1}, x_{t}\right]+b_{c}\right)
\end{aligned}
$$

Selanjutnya proses menentukan data masukan (input gates) dengan rumus sebagai berikut:

$$
\mathrm{C}_{\mathrm{t}}=\mathrm{f}_{\mathrm{t}} * \mathrm{C}_{\mathrm{t}-1}+\mathrm{i}_{\mathrm{t}} * \mathrm{C}_{\mathrm{t}}
$$

Selanjutnya proses menentukan nilai keluaran (output gates). Terdapat dua proses pada proses menentukan nilai keluaran dengan rumus sebagai berikut:

$$
\begin{aligned}
& o_{t}=\sigma\left(W_{o} \cdot\left[h_{t-1}, x_{t}\right]+b_{o}\right) \\
& h_{t}=o_{t} * \tanh \left(C_{t}\right)
\end{aligned}
$$

Selajutnya proses menghitung nilai loss dengan persamaan sebagai berikut:

$$
M S E=\frac{1}{n} \sum_{i=1}^{n}\left(f_{i}-y_{i}\right)^{2}
$$

\section{METODE}

Secara umum tahapan penelitian terdiri dari identifikasi masalah, pengumpulan data, preprocessing data, perancangan model LSTM, pelatihan, dan pengujian. Tahapan penelitian bisa dilihat pada gambar 1 .

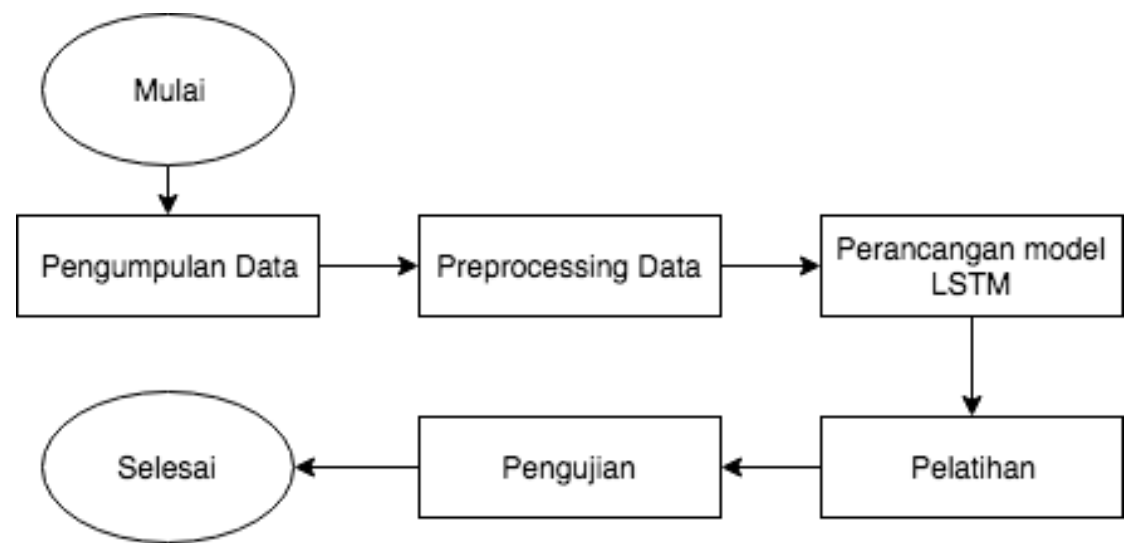

Gambar 1. Tahapan penelitian 
PETIR: Jurnal Pengkajian dan Penerapan Teknik Informatika Vol. 13, No. 1, Maret 2020, P-ISSN 1978-9262, E-ISSN 2655-5018 DOI: https://doi.org/10.33322/petir.v13i1.858

Pada gambar 1, pengumpulan data yang digunakan menggunakan 2 data yaitu data saham dan harga kurs. Data saham yang digunakan diambil dari situs yahoo finance, sedangkan harga kurs yang digunakan diambil dari situ OFX. Data yang diperoleh pada pengumpulan data masih berupa data mentah sehingga diperlukan preprocessing data yang meliputi penggabungan data, mengisi data kosong, pembagian data, normalisasi data dan pengelompokan data. Dalam proses peramalan harga saham, dibutuhkan data latih dan data uji, pembagian data ini digunakan untuk membedakan antara data yang digunakan untuk proses pelatihan dan data yang digunakan untuk proses pengujian. Setelah dilakukan proses pembagian data, data yang dihasilkan memiliki nilai yang bervariasi, oleh sebab itu untuk meminimalisir error maka dilakukan normalisasi data. Proses normalisasi yang digunakan adalah min-max scalling[14]. Setelah dilakukan normalisasi data, dilanjutnya dengan pengelompokan data.

\subsection{Perancangan Model LSTM}

Perancangan dengan algoritma LSTM dimulai dengan inisialisasi parameter yang diproses oleh LSTM, parameter yang digunakan adalah lapisan tersembunyi (hidden layer), memori sel (neuron), putaran (epoch) dan jumlah sampel data (batch size).

\subsection{Pelatihan}

Tahapan dalam pelatihan LSTM dimulai dengan inisialisasi bobot awal, dilanjutkan dengan pemprosesan sel LSTM yang dimulai dengan menentukan nilai yang tidak digunakan dengan persamaan (1), menentukan nilai masukan dengan persamaan (2) dan (3), memperbaharui sel dengan persamaan (4) dan menentukan nilai keluaran dengan persamaan (5) dan (6). Setelah diproses dengan LSTM dilanjutkan dengan menghitung nilai loss dengan persamaan (7). Hasil dari nilai loss dioptimasi dengan menggunakan RMSProp. Proses pelatihan ini dilakukan sebanyak putaran yang telah ditentukan[15].

\subsection{Pengujian}

Setelah dilakukan proses pelatihan, selanjutnya proses pengujian dengan parameter yang dihasilkan dari hasil pelatihan dengan menggunakan data uji.

\section{HASIL DAN PEMBAHASAN}

Data saham yang digunakan yaitu PT. Unilever Tbk (UNVR.JK), PT. Kimia Farma (KAEF.JK) dan PT. Gudang Garam Tbk (GGRM.JK) pada tahun 2016 sampai 2019 dengan menggunakan skenario pengujian sebagai berikut:

a. Jumlah lapisan tersembunyi $=1,2,3,4,5$

b. Jumlah sel memori $=50,75,100,125,150$

c. Jumlah kelompok data $=10,20,30,40,50$

d. Jumlah putaran $=10,20,30,40,50$

Bobot awal yang digunakan secara acak sehingga tidak diketahui nilai bobot yang digunakan, oleh karena itu dilakukan observasi sebanyak 3 kali untuk mendapatkan hasil yang baik.

\subsection{Menentukan Lapisan Tersembunyi}

Kombinasi lapisan yang digunakan pada proses pelatihan adalah 1, 2, 3, 4, dan 5. Tabel 1 merupakan merupakan hasil pelatihan dengan kombinasi dari lapisan tersembunyi. 
PETIR: Jurnal Pengkajian dan Penerapan Teknik Informatika Vol. 13, No. 1, Maret 2020, P-ISSN 1978-9262, E-ISSN 2655-5018 DOI: https://doi.org/10.33322/petir.v13i1.858

Tabel 1. Hasil pelatihan kombinasi lapisan tersembunyi

\begin{tabular}{|c|c|c|c|c|c|c|}
\hline No & Lapisan & Memori sel & $\begin{array}{c}\text { Sampel } \\
\text { data }\end{array}$ & Putaran & $\begin{array}{c}\text { Waktu } \\
\text { latih }\end{array}$ & Loss \\
\hline 1. & 1 & 50 & 10 & 10 & $1 \mathrm{~m} 28 \mathrm{~s}$ & 0.0027 \\
\hline 2. & 2 & 50 & 10 & 10 & $3 \mathrm{~m} 29 \mathrm{~s}$ & 0.0031 \\
\hline 3. & 3 & 50 & 10 & 10 & $5 \mathrm{~m} 18 \mathrm{~s}$ & 0.0044 \\
\hline 4. & 4 & 50 & 10 & 10 & $7 \mathrm{~m} 1 \mathrm{~s}$ & 0.0058 \\
\hline 5. & 5 & 50 & 10 & 10 & $912 \mathrm{~s}$ & 0.0073 \\
\hline
\end{tabular}

Tabel 1 menunjukan bawah 1 lapisan tersembunyi memiliki nilai loss yang paling kecil yaitu 0.0027 dengan waktu latih 1 menit 28 detik, sedangkan 5 lapisan tersembunyi memiliki nilai loss dan waktu latih yang tertinggi. Semakin banyak lapisan tersembunyi yang digunakan maka semakin lama waktu latih yang dibutuhkan. Tabel 2 merupakan hasil uji dari kombinasi lapisan tersembunyi.

Tabel 2. Hasil uji kombinasi lapisan tersembunyi.

\begin{tabular}{|c|c|c|c|c|}
\hline No & Lapisan & UNVR.JK & KAEF.JK & GGRM.JK \\
\hline 1. & 1 & 0.0023 & 0.0020 & 0.0023 \\
\hline 2. & 2 & 0.0024 & 0.0023 & 0.0026 \\
\hline 3. & 3 & 0.0032 & 0.0030 & 0.0032 \\
\hline 4. & 4 & 0.0058 & 0.0039 & 0.0041 \\
\hline 5. & 5 & 0.0063 & 0.0042 & 0.0052 \\
\hline
\end{tabular}

Tabel 2 merupakan hasil uji dari kombinasi lapisan tersembunyi dengan data uji pada 3 perusahaan, hasil terbaik yang diperoleh adalah dengan menggunakan 1 lapisan dengan nilai loss pada saham UNVR.JK sebesar 0.0023, KAEF.JK sebesar 0.0020 dan GGRM.JK sebesar 0.0023.

\subsection{Menentukan jumlah memori sel}

Kombinasi memori sel yang digunakan adalah 50, 75, 100, 125 dan 150. Tabel 3 merupakan hasil pelatihan dengan kombinasi memori sel.

Tabel 3. Hasil pelatihan kombinasi memori sel

\begin{tabular}{|c|c|c|c|c|c|c|}
\hline No & Lapisan & Memori sel & Sampel data & Putaran & $\begin{array}{c}\text { Waktu } \\
\text { latih }\end{array}$ & Loss \\
\hline 1. & 1 & 50 & 10 & 50 & $1 \mathrm{~m} 28 \mathrm{~s}$ & 0.0027 \\
\hline 2. & 1 & 75 & 10 & 50 & $1 \mathrm{~m} \mathrm{50s}$ & 0.0021 \\
\hline 3. & 1 & 100 & 10 & 50 & $1 \mathrm{~m} 50 \mathrm{~s}$ & 0.0022 \\
\hline 4. & 1 & 125 & 10 & 50 & $1 \mathrm{~m} 52 \mathrm{~s}$ & 0.0020 \\
\hline 5. & 1 & 150 & 10 & 50 & $1 \mathrm{~m} 54 \mathrm{~s}$ & 0.0020 \\
\hline
\end{tabular}

Tabel 3 menunjukkan bahwa 50 memori sel memiliki nilai loss yang paling tinggi yaitu 0.0027 dengan waktu latih 1 menit 28 detik Sedangkan 125 dan 150 memori sel memiliki nilai loss paling kecil yaitu 0.0020. Semakin banyak memori sel yang digunakan, maka semakin kecil nilai loss yang dihasilkan, namun memiliki waktu latih yang semakin lama. Tabel 4 merupakan hasil uji dari kombinasi memori sel. 
Tabel 4. Hasil uji kombinasi memori sel.

\begin{tabular}{|c|c|c|c|c|}
\hline No & Memori sel & UNVR.JK & KAEF.JK & GGRM.JK \\
\hline 1. & 50 & 0.0023 & 0.0020 & 0.0023 \\
\hline 2. & 75 & 0.0019 & 0.0016 & 0.0019 \\
\hline 3. & 100 & 0.0028 & 0.0024 & 0.0027 \\
\hline 4. & 125 & 0.0021 & 0.0018 & 0.0022 \\
\hline 5. & 150 & 0.0018 & 0.0015 & 0.0019 \\
\hline
\end{tabular}

Tabel 4 merupakan hasil uji dari kombinasi memori sel dengan data uji pada 3 perusahaan, hasil terbaik yang diperoleh adalah dengan menggunakan 150 memori sel dengan nilai loss pada saham UNVR.JK sebesar 0.0018, KAEF.JK sebesar 0.0015 dan GGRM.JK sebesar 0.0019.

\subsection{Menentukan jumlah sampel data}

Kombinasi jumlah sampel data yang digunakan adalah 10, 20, 30, 40, 50. Tabel 5 merupakan hasil pelatihan dari kombinasi jumlah sampel data.

Tabel 5. Hasil pelatihan kombinasi jumlah sampel data

\begin{tabular}{|c|c|c|c|c|c|c|}
\hline No & Lapisan & Memori sel & $\begin{array}{c}\text { Sampel } \\
\text { data }\end{array}$ & Putaran & $\begin{array}{c}\text { Waktu } \\
\text { latih }\end{array}$ & Loss \\
\hline 1. & 1 & 150 & 10 & 10 & $1 \mathrm{~m} 54 \mathrm{~s}$ & 0.0027 \\
\hline 2. & 1 & 150 & 20 & 10 & $1 \mathrm{~m}$ & 0.0024 \\
\hline 3. & 1 & 150 & 30 & 10 & $41.7 \mathrm{~s}$ & 0.0027 \\
\hline 4. & 1 & 150 & 40 & 10 & $32.9 \mathrm{~s}$ & 0.0031 \\
\hline 5. & 1 & 150 & 50 & 10 & $27.6 \mathrm{~s}$ & 0.0037 \\
\hline
\end{tabular}

Tabel 5 menunjukkan bahwa dengan 50 sampel data memiliki nilai loss yang paling tinggi yaitu 0.0037 dengan waktu latih 27.6 detik, sedangkan 20 sampel data memiliki nilai loss paling kecil yaitu 0.0024 dengan waktu latih 1 menit. Semakin banyak sampel data yang disebarkan maka semakin sedikit waktu latih yang dibutuhkan. Tabel 6 merupakan hasil uji dari kombinasi jumlah sampel data.

Tabel 6. Hasil uji kombinasi jumlah sampel data

\begin{tabular}{|c|c|c|c|c|}
\hline No & Sampel data & UNVR.JK & KAEF.JK & GGRM.JK \\
\hline 1. & 10 & 0.0017 & 0.0014 & 0.0018 \\
\hline 2. & 20 & 0.0019 & 0.0016 & 0.0020 \\
\hline 3. & 30 & 0.0028 & 0.0026 & 0.0030 \\
\hline 4. & 40 & 0.0027 & 0.0023 & 0.0024 \\
\hline 5. & 50 & 0.0033 & 0.0031 & 0.0035 \\
\hline
\end{tabular}

Tabel 6 merupakan hasil uji dari kombinasi dari jumlah sampel data dengan data uji pada 3 perusahaan, hasil terbaik yang diperoleh adalah dengan menggunakan 10 sample data dengan nilai loss pada saham UNVR.JK sebesar 0.0017, KAEF.JK sebesar 0.0014 dan GGRM.JK sebesar 0.0018.

\subsection{Menentukan jumlah putaran}

Kombinasi jumlah putaran yang digunakan adalah 10, 20, 35, 40 dan 50. Tabel 7 merupakan hasil pelatihan dari kombinasi jumlah putaran. 
PETIR: Jurnal Pengkajian dan Penerapan Teknik Informatika Vol. 13, No. 1, Maret 2020, P-ISSN 1978-9262, E-ISSN 2655-5018 DOI: https://doi.org/10.33322/petir.v13i1.858

Tabel 7. Hasil pelatihan kombinasi jumlah putaran

\begin{tabular}{|c|c|c|c|c|c|c|}
\hline No & Lapisan & Memori sel & $\begin{array}{c}\text { Sampel } \\
\text { data }\end{array}$ & Putaran & $\begin{array}{c}\text { Waktu } \\
\text { latih }\end{array}$ & Loss \\
\hline 1. & 1 & 150 & 10 & 10 & $1 \mathrm{~m} 54 \mathrm{~s}$ & 0.0027 \\
\hline 2. & 1 & 150 & 10 & 20 & $3 \mathrm{~m} 47 \mathrm{~s}$ & 0.0017 \\
\hline 3. & 1 & 150 & 10 & 30 & $5 \mathrm{~m} 40 \mathrm{~s}$ & 0.0015 \\
\hline 4. & 1 & 150 & 10 & 40 & $7 \mathrm{~m} 32 \mathrm{~s}$ & 0.0013 \\
\hline 5. & 1 & 150 & 10 & 50 & $9 \mathrm{~m} 24 \mathrm{~s}$ & 0.0014 \\
\hline
\end{tabular}

Tabel 7 menunjukkan bahwa 10 putaran memiliki nilai loss paling tinggi yaitu 0.0027 dengan waktu latih 1 menit 54 detik, sedangkan 40 putaran memiliki nilai loss paling kecil dengan waktu 7 menit 32 detik. Semakin banyak putaran yang digunakan maka semakin banyak waktu latih yang dibutuhkan. Dengan bertambahnya nilai putaran tidak selalu menghasilkan nilai loss yang lebih kecil, seperti tabel 7 nomer 4 memiliki nilai loss yang lebih kecil dibandingkan dengan nomer 5 . Tabel 8 merupakan hasil uji dari kombinasi jumlah putaran.

Tabel 8. Hasil uji kombinasi jumlah putaran

\begin{tabular}{|c|c|c|c|c|}
\hline No & Putaran & UNVR.JK & KAEF.JK & GGRM.JK \\
\hline 1. & 10 & 0.0018 & 0.0015 & 0.0019 \\
\hline 2. & 20 & 0.0016 & 0.0013 & 0.0017 \\
\hline 3. & 30 & 0.0016 & 0.0013 & 0.0017 \\
\hline 4. & 40 & 0.0016 & 0.0013 & 0.0017 \\
\hline 5. & 50 & 0.0018 & 0.0014 & 0.0018 \\
\hline
\end{tabular}

Tabel 8 merupakan hasil uji dari kombinasi dari jumlah putaran dengan data uji pada 3 perusahaan, hasil terbaik yang diperoleh adalah dengan menggunakan 20 putaran dengan nilai loss pada saham UNVR.JK sebesar 0.0016, KAEF.JK sebesar 0.0013 dan GGRM.JK sebesar 0.0017.

Hasil terbaik yang diperoleh setelah menentukan parameter adalah dengan menggunakan 1 lapisan tersembunyi, 150 memori sel, 10 kelompok data, dan 20 putaran dengan nilai MSE pada saham UNVR.JK sebesar 0.0016, KAEF.JK sebesar 0.0013 dan GGRM.JK sebesar 0.0017. Gambar 2 adalah perbandingan grafik saham asli UNVR.JK dengan grafik data prediksi.

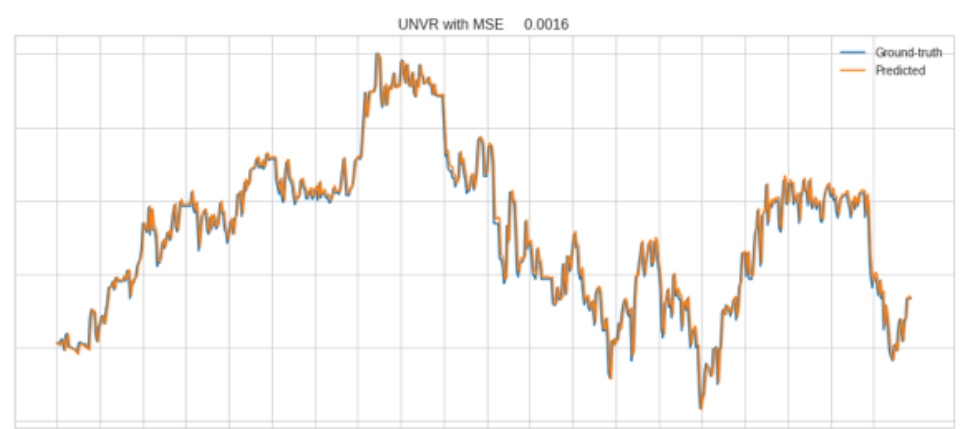

Gambar 2. Perbandingan hasil prediksi

Pada gambar 2 terdapat dua warna grafik yaitu grafik warna biru dan jingga. Grafik warna biru adalah grafik asli saham UNVR.JK sedangkan grafik warna biru adalah grafik data prediksi. Kedua grafik tersebut memiliki pola yang sama, dengan hasil MSE sebesar 0.0016 terhadap data asli pada saham UNVR.JK. 
PETIR: Jurnal Pengkajian dan Penerapan Teknik Informatika Vol. 13, No. 1, Maret 2020, P-ISSN 1978-9262, E-ISSN 2655-5018 DOI: https://doi.org/10.33322/petir.v13i1.858

Setelah dilakukan pengujian dengan hasil diatas, maka dilakukan perbandingan dengan menggunakan algoritma SVR.

\subsection{Perbandingan LSTM dengan SVR}

Pengujian LSTM dengan SVR yang dilakukan adalah dengan menggunakan parameter rentang data selama 1,30 dan 60 hari. Rentang data adalah banyaknya data yang digunakan untuk melakukan prediksi pada hari berikutnya. Pengujian dilakukan untuk menunjukan pengaruh rentang data terhadap kedua algoritma tersebut.

\subsubsection{Perbandingan rendang data 1 hari}

Perbandingan yang dilakukan dengan rentang data 1 hari adalah dengan membandingkan MSE dan waktu latih yang dihasilkan oleh kedua algoritma tersebut. Tabel 9 merupakan hasil perbandingan LSTM dengan SVR dengan rentang data 1 hari.

Tabel 9. Hasil pelatihan kombinasi rentang data 1 hari

\begin{tabular}{|c|c|c|c|}
\hline No & Pembanding & LSTM & SVR \\
\hline 1. & Rentang data & 1 & 1 \\
\hline 2. & Waktu latih & $7 \mathrm{~min} 54 \mathrm{~s}$ & $9 \mathrm{~s}$ \\
\hline 3. & MSE & 0.0013 & 0.0025 \\
\hline
\end{tabular}

Dari sisi waktu yang diperlukan dalam proses pelatihan dengan rentang data 1 hari, SVR memiliki waktu yang lebih cepat dibandingkan dengan LSTM. Jika dilihat dari MSE yang dihasilkan, LSTM memiliki MSE yang lebih kecil dibandingkan dengan SVR. Selisih nilai MSE yang dihasilkan dengan menggunakan 1 rentang data adalah 0.0012. Gambar 3 adalah grafik perbandingan saham UNVR dengan menggunakan LSTM dan SVR dengan rentang data 1 hari.

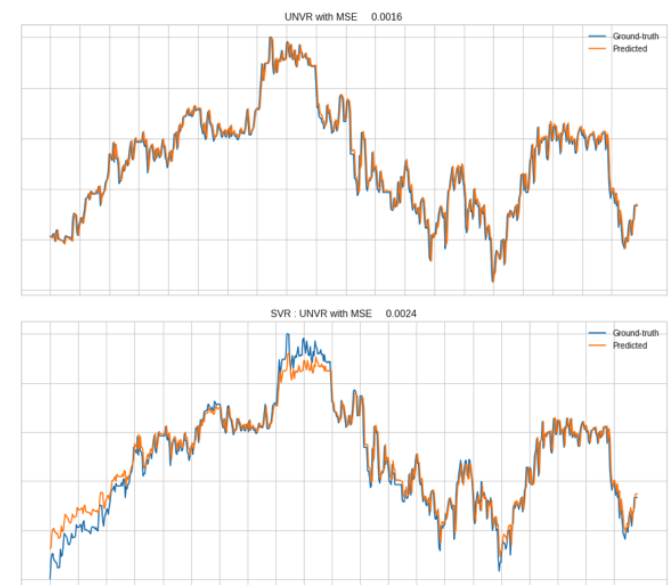

Gambar 3. Perbandingan LSTM dengan SVR dengan rentang data 1 hari

Dari hasil perbandingan dengan menggunakan rentang data 1 hari, nilai loss pada proses pelatihan dan hasil MSE pada pengujian memiliki selisih yang tidak jauh berbeda, oleh sebab itu dilakukan proses perbandingan dengan meggunakan rentang data 30 hari. 
PETIR: Jurnal Pengkajian dan Penerapan Teknik Informatika Vol. 13, No. 1, Maret 2020, P-ISSN 1978-9262, E-ISSN 2655-5018 DOI: https://doi.org/10.33322/petir.v13i1.858

\subsubsection{Perbandingan rendang data 30 hari}

Pada perbandingan dengan menggunakan rentang data 1 hari, selisih MSE yang dihasilkan tidak jauh berbeda, oleh sebab itu dilakukan proses perbandingan dengan 30 rentang data. Tabel 10 merupakan hasil perbandingan LSTM dengan SVR dengan rentang data 30 hari.

Tabel 10. Hasil pelatihan kombinasi rentang data 30 hari

\begin{tabular}{|c|c|c|c|}
\hline No & Pembanding & LSTM & SVR \\
\hline 1. & Rentang data & 30 & 30 \\
\hline 2. & Waktu latih & $7 \min 32 \mathrm{~s}$ & $9 \mathrm{~s}$ \\
\hline 3. & MSE & 0.0016 & 0.0045 \\
\hline
\end{tabular}

Pada tabel 10 nilai loss yang dihasilkan pada proses pelatihan dengan menggunakan LSTM lebih kecil dari SVR dengan selisih 0.0032, sedangkan waktu yang dibutuhkan pada LSTM lebih lama dari SVR. Pada hasil uji, nilai MSE yang dihasilkan oleh LSTM lebih baik dari SVR dengan selisih yang bertambah banyak dibandingkan dengan menggunakan rentang data 1 hari. Gambar 4 adalah grafik perbandingan saham UNVR dengan menggunakan LSTM dan SVR dengan rentang data 30 hari.

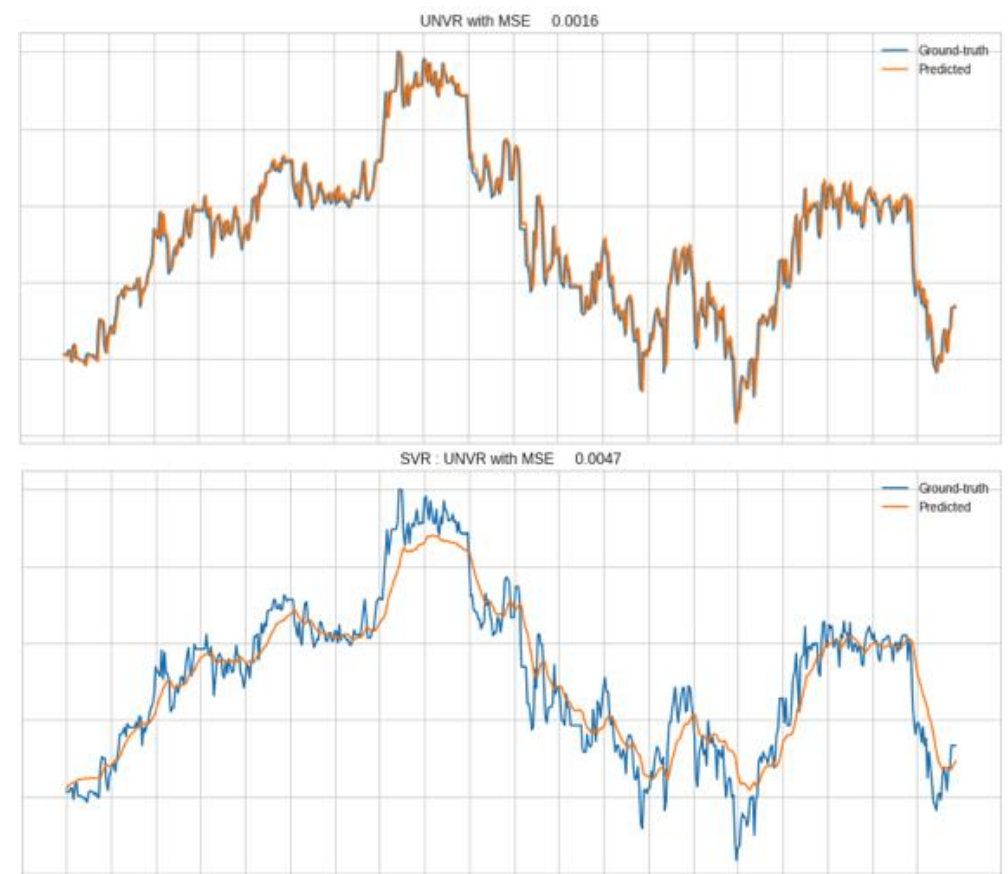

Gambar 4. Perbandingan LSTM dengan SVR dengan rentang data 30 hari

Dari hasil perbandingan dengan menggunakan rentang data 30 hari, nilai loss pada proses pelatihan dan hasil MSE pada SVR memiliki selisih yang jauh berbeda dibandingkan dengan menggunakan rentang data 1 hari, sedangkan nilai yang dihasilkan LSTM tetap sama.

\subsubsection{Perbandingan rendang data 60 hari}

Pada perbandingan dengan menggunakan rentang data 30 hari, selisih MSE yang dihasilkan semakin besar dibandingan dengan menggunakan rentang data 1 hari, jika menggunakan rentang data 60 hari, MSE yang dihasilkan oleh SVR semakin bertambah. Tabel 11 merupakan hasil perbandingan LSTM dengan SVR dengan rentang data 60 hari. 
PETIR: Jurnal Pengkajian dan Penerapan Teknik Informatika Vol. 13, No. 1, Maret 2020, P-ISSN 1978-9262, E-ISSN 2655-5018 DOI: https://doi.org/10.33322/petir.v13i1.858

Tabel 11. Hasil pelatihan kombinasi rentang data 60 hari

\begin{tabular}{|c|c|c|c|}
\hline No & Pembanding & LSTM & SVR \\
\hline 1. & Rentang data & 60 & 60 \\
\hline 2. & Waktu latih & $8 \min 39 \mathrm{~s}$ & $10 \mathrm{~s}$ \\
\hline 3. & MSE & 0.0013 & 0.0065 \\
\hline
\end{tabular}

Tabel 11 merupakan perbandingan LSTM dengan SVR dengan menggunakan 60 rentang data, nilai MSE yang dihasilkan oleh SVR semakin bertambah seiring dengan bertambahnya jumlah rentang data. Gambar 5 adalah grafik perbandingan saham UNVR dengan menggunakan LSTM dan SVR dengan rentang data 60 hari.

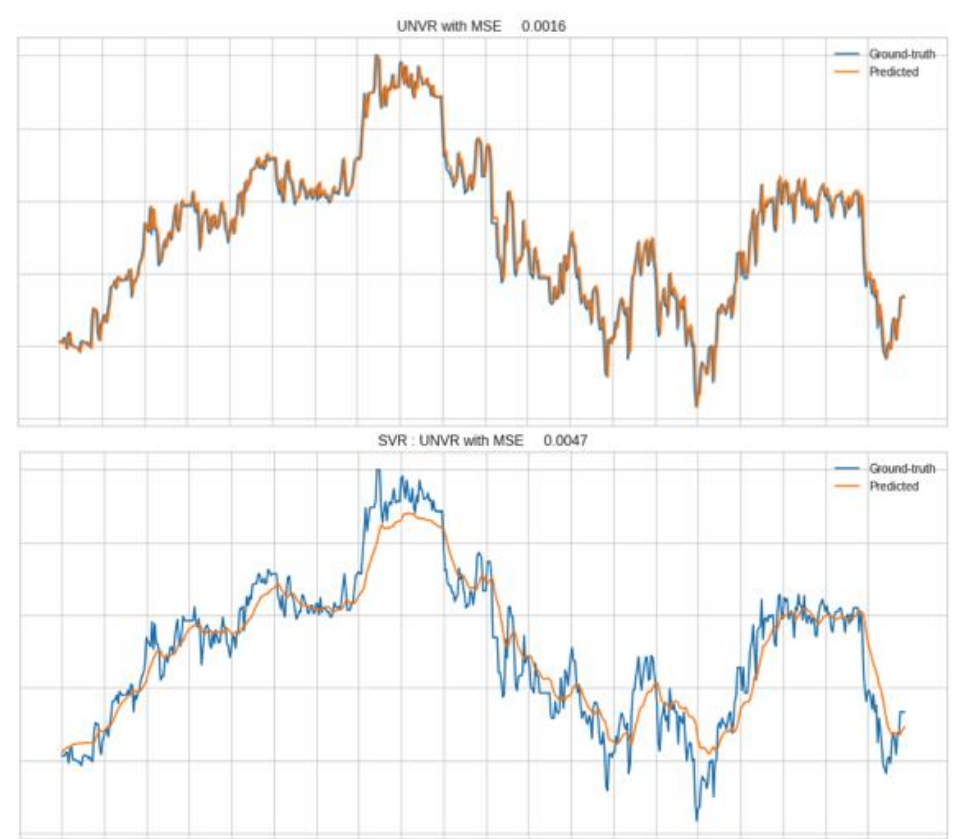

Gambar 5. Perbandingan LSTM dengan SVR dengan rentang data 60 hari

Jika dibandingkan dengan rentang data sebelumnya, nilai MSE yang dihasilkan oleh LSTM tidak dipengaruhi oleh rentang data namun berpengaruh pada waktu latih.

\section{KESIMPULAN DAN SARAN}

Secara umum semakin besar rentang data yang digunakan oleh SVR, maka semakin besar nilai MSE yang dihasilkan. Sedangkan nilai MSE yang dihasilkan LSTM memiliki nilai yang sama walaupun menggunakan rentang data yang berbeda. Berdasarkan hasil pengujian, LTSM mampu memprediksi harga saham pada tahun 2017-2019 dengan performa yang baik, hal ini ditunjukkan dengan tingkat kesalahan yang kecil. Dengan demikian dapat disimpulkan bahwa LSTM mampu menanggulangi ketergantungan jangka panjang dan mampu memprediksi harga saham dengan hasil yang akurat.

Proses pelatihan yang dilakukan oleh LSTM memiliki waktu yang lebih lama dibandingkan dengan SVR, saran dari penelitian ini adalah membangun metode peralaman dengan proses pelatihan yang cepat, akurat dan mampu menanggulangi ketergantungan jangka panjang. 
PETIR: Jurnal Pengkajian dan Penerapan Teknik Informatika Vol. 13, No. 1, Maret 2020, P-ISSN 1978-9262, E-ISSN 2655-5018 DOI: https://doi.org/10.33322/petir.v13i1.858

\section{DAFTAR PUSTAKA}

[1] Trippi, Robert \& Desieno, Duane. (1992). Trading Equity Index Futures With a Neural Network. Journal of Portfolio Management - J PORTFOLIO MANAGE. 19. 27-33. 10.3905/jpm.1992.409432.

[2] Downes, J., Goodman, J. E., and Budhidarmo, S. (1999). Kamus Istilah Keuangan dan Investasi, Elex Media Komputindo. Nama penerbit

[3] Abd. Majid, M. Shabri. (2014). Dampak Nilai Kurs dan Suku Bunga Terhadap Harga Saham di Indonesia. Jurnal Ekonomi dan Bisnis. 8. 51-57.

[4] Purnama, Rizal. (2017). Perancangan Prediksi Untuk Menentukan Indeks Harga Saham Menggunakan Jaringan Syaraf Tiruan. Kinetik. 2. 125. 10.22219/kinetikv2i2.190.

[5] Wartati, D., \& Masruroh, N. A. (2017). Aplikasi Jaringan Saraf Tiruan dan Particle Swarm Optimization untuk Peramalan Indeks Harga Saham Bursa Efek Indonesia. Jurnal Teknosains, 6(1), 22-30.

[6] Siahaan, Lisbeth. (2017). Prediksi Indeks Harga Saham dengan Metode Gabungan Support Vector Regression dan Jaringan Syaraf Tiruan. Indonesian Journal on Computing (Indo-JC). 2. 21. 10.21108/INDOJC.2017.2.1.45.

[7] Hochreiter, Sepp \& Schmidhuber, Jürgen. (1997). Long Short-term Memory. Neural computation. 9. 1735-80. 10.1162/neco.1997.9.8.1735.

[8] Basak, Debasish \& Pal, Srimanta \& Patranabis, Dipak. (2007). Support Vector Regression. Neural Information Processing - Letters and Reviews. 11.

[9] Khanna, Rahul \& Awad, Mariette. (2015). Efficient Learning Machines: Theories, Concepts, and Applications for Engineers and System Designers. 10.1007/978-1-4302-5990-9.

[10] D'informatique, D \& N, Ese \& Esent, Pr \& Au, Ee \& Gers, Felix \& Hersch, Prof \& Esident, Pr \& Frasconi, Prof. (2001). Long Short-Term Memory in Recurrent Neural Networks. 10.5075/epfl-thesis-2366.

[11] Hendri, H. (2014). Character Recognition Dengan Menggunakan Jaringan Syaraf Tiruan. Jurnal TIMES, 3(2), 1-5.

[12] Roondiwala, Murtaza \& Patel, Harshal \& Varma, Shraddha. (2017). Predicting Stock Prices Using LSTM. International Journal of Science and Research (IJSR). 6. 10.21275/ART20172755.

[13] Aldi, M. W. P., Jondri, J., \& Aditsania, A. (2018). Analisis Dan Implementasi Long Short Term Memory Neural Network Untuk Prediksi Harga Bitcoin. eProceedings of Engineering, $5(2)$.

[14] PATRO, S GOPAL \& Sahu, Kishore Kumar. (2015). Normalization: A Preprocessing Stage. IARJSET. 10.17148/IARJSET.2015.2305.

[15] Staudemeyer, Ralf \& Morris, Eric. (2019). Understanding LSTM -- a tutorial into Long ShortTerm Memory Recurrent Neural Networks. 